DOI: $10.24850 / \mathrm{j}-$ tyca-2021-04-07

Articles

\title{
Permeable concrete design for heavy metal absorption in sustainable roads
}

\section{Diseño de concreto permeable para absorción de metales pesados en carreteras sustentables}

Juan F. Silva-Juarez ${ }^{1}$, ORCID: https://orcid.org/0000-0002-5668-681X

Omar Chavez-Alegria², ORCID: https://orcid.org/0000-0003-4474-0206

J. Ramon Gaxiola-Camacho3, ORCID: https://orcid.org/0000-00029230-8111

Jesus R. Millan-Almaraz ${ }^{4}$, ORCID: https://orcid.org/0000-0002-38003712

${ }^{1}$ Departamento de Ingeniería Civil, Universidad Autónoma de Querétaro, Querétaro, Mexico, franciscosiju@gmail.com

2Departamento de Ingeniería Civil, Universidad Autónoma de Querétaro, Querétaro, Mexico, omar.chavez@uaq.mx

${ }^{3}$ Facultad de Ingeniería, Universidad Autónoma de Sinaloa, Sinaloa, Mexico, jrgaxiola@uas.edu.mx

${ }^{4}$ Facultad de Ciencias Físico Matemáticas, Universidad Autónoma de Sinaloa, Sinaloa, Mexico, jrmillan@uas.edu.mx 
Tecnología y

Ciencias $₫$ Agua
2021, Instituto Mexicano de Tecnología del Agua

Open Access bajo la licencia CC BY-NC-SA 4.0

(https://creativecommons.org/licenses/by-nc-sa/4.0/)

Corresponding author: Jesus R. Millan-Almaraz, jrmillan@uas.edu.mx

\section{Abstract}

Nowadays, there is a great amount of heavy metals on highways and parking lots. For example, some of such heavy metals are generated mainly by factors as fuel and lubricants leakages, vehicles rust, and carbon emissions. Because of this and some other factors, water pollution occurs due to superficial slurring. In this paper, the application of natural basaltic rocks as an additive for permeable concrete mixtures is presented. During this process, the batch adsorption method is used to determine the effectiveness of the proposed material in removing arsenic (As), zinc ( $\mathrm{Zn})$, and cadmium (Cd) concentrations that are typically found in low transit highways and other hydraulic infrastructure. The adsorption test was carried out by immersing $50 \mathrm{~mm} \times 100 \mathrm{~mm}$ permeable concrete cylinders in 1-L beakers for $96 \mathrm{~h}$ using standard As, $\mathrm{Zn}$, and $\mathrm{Cd}$ reagents with 10, 30, 50, and $90 \mathrm{mg} / \mathrm{l}$ concentrations, respectively. Results demonstrated that the retention efficiencies were decreased when As and Zn concentrations were increased. However, Cd presented better elimination levels at $90 \mathrm{mg} / \mathrm{l}$ concentration where results determined a $\mathrm{Cd}$ elimination up to $89 \%, 98 \%$ for As, and $75 \%$ for Zn. Finally, based on the results, it is proposed a new methodology for the classification and characterization of basaltic rocks, such a methodology represents a novel process to design permeable concrete material using X-ray fluorescence spectrometry as the base to determine heavy metal absorption on concrete materials. The presented approach will contribute to the 
Ciencias $₫$ Agua
2021, Instituto Mexicano de Tecnología del Agua

Open Access bajo la licencia CC BY-NC-SA 4.0

(https://creativecommons.org/licenses/by-nc-sa/4.0/)

improvement of environmental conditions before water treatment processes.

Keywords: Adsorption test, environmental engineering, permeable concrete, heavy metal adsorption.

\section{Resumen}

Actualmente existe una gran cantidad de metales pesados en carreteras y estacionamientos. Por ejemplo, algunos de estos metales pesados son generados principalmente por factores como fugas de combustibles y lubricantes, oxidación de vehículos y emisiones de carbono. Debido a lo anterior y otros factores ocurre contaminación de aguas debido al escurrimiento superficial. En este artículo se presenta la aplicación de rocas basálticas naturales como aditivo para mezclas de concretos permeables. Durante este proceso, el método de adsorción por lotes se utilizó para determinar la efectividad del material propuesto, a fin de eliminar arsénico (As), zinc (Zn) y cadmio (Cd) típicamente encontrados en carreteras de bajo tráfico e infraestructura hidráulica. La prueba de adsorción se llevó a cabo sumergiendo cilindros de concreto permeable de $50 \mathrm{~mm} \times 100 \mathrm{~mm}$ en vasos de precipitado de un litro por un periodo de 96 horas usando reactivos estándares de As, Zn y Cd en concentraciones de 10, 3050 y 90 mg/l, respectivamente. Los resultados demostraron que las eficiencias de retención disminuyeron cuando las concentraciones de As y Zn se incrementaron. Sin embargo, se presentó una mejor eliminación de $\mathrm{Cd}$ a un nivel de $90 \mathrm{mg} / \mathrm{l}$, donde los resultados determinaron una eliminación de Cd de hasta $89 \%$, 98 \% para As y 75 $\%$ para $\mathrm{Zn}$. Finalmente, con base en los resultados, se propone una nueva 
metodología para clasificación y caracterización de rocas basálticas para diseñar materiales de concreto permeable usando espectrometría de fluorescencia de rayos $X$ como base para determinar adsorción de metales pesados en concretos permeables. El presente proyecto contribuirá a la mejora de condiciones ambientales previas al proceso de tratamiento de aguas.

Palabras clave: prueba de adsorción, ingeniería ambiental, concreto permeable, adsorción de metales pesados.

Received: $15 / 06 / 2020$

Accepted: 10/09/2020

\section{Introduction}

The literature ( $\mathrm{Li}$, Zhang, Liu, \& Peng, 2017) documented that environmental problems, such as floods, water pollution, climate, and urban phenomena as urban heat islands, are due to the lack of sustainable drainage systems capable of mitigating these problems. In this sense, Uma-Maguesvari et al. (2013) and Starke, Wallmeyer, Rölver, Göbel, and Coldewey (2011) reported that the sections of permeable pavements can purify the rain beforehand, and such pavements can be categorized as 
tunnels for the exchange of heat between the humidity of the environment and the pavement. This will yield positive environmental effects as maintaining the aquifer equilibrium, and the relief of heat island phenomena.

In addition to the above, impermeable infrastructure may transport pollutants to the water channels and aquifers (Javadi, Abdollahian, Zhao, Ghavami, \& Rockaway, 2016). Furthermore, some other scholars as Sandahl, Baldwin, Jenkins and Scholz (2007), and Haselbach, Poor, and Tilson (2014) reported that surface runoff contains high levels of heavy metals such as $\mathrm{Zn}$ and $\mathrm{Cu}$, such metals represent a threat if they are discharged directly to water channels, rivers or water storage systems. The presence of these contaminants in surface waters has become a serious environmental problem, mainly because these metals are not biodegradable and can be incorporated into the food chain and, therefore, they represent serious problems to human health (Ammar, Ismail, \& ElShafey, 2016). Along with the above-mentioned problem, in roads and parking lots, the contribution of heavy metals is mainly caused by leaks of fuel and lubricants, body rust, tire wear, brakes, and carbon dioxide emissions (Turer, 2005; Mangani, Berloni, Bellucci, Tatàno, \& Maione, 2005). In this sense, Birch and Scollen (2003) found that the highest concentrations of heavy metals in gutters are due to the high wind speed generated by vehicles near the road.

In recent investigations (Sounthararajah, Loganathan, Kandasamy, \& Vigneswaran, 2017), the use of permeable pavements has been studied, principally related to water treatment. In the above investigation, it was observed that the combination of a treatment based on a mixture of zeolite and basalt, in different concentrations, generated a good quality 
Tecnología y

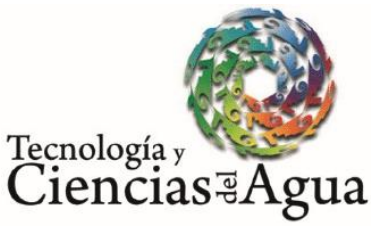

2021, Instituto Mexicano de Tecnología del Agua

Open Access bajo la licencia CC BY-NC-SA 4.0

(https://creativecommons.org/licenses/by-nc-sa/4.0/)

of the water according to the marine environment water standards, eliminating heavy metals, which are produced by different sources of pollutants and currently transported to the oceans by surface runoff and aquifers due to their infiltration. Another important aspect in the use of permeable concrete design is the type of stone aggregate used in the composition of the mixture (Weiss, Kayhanian, Gulliver, \& Khazanovich, 2017). Parallel to the above investigations, to determine which material has better properties for the absorption of heavy metals such as $\mathrm{Pb}$ and Zn from surface runoff, Zhao and Zhao (2014) used a porous asphalt with 3 pavement models, the first one with the implementation of basalt, the second with limestone, and the third one using a combination of basaltlimestone, total lead, and zinc concentrations were remarkably reduced throughout the initial flush, showing, on average, reductions of 90 and $80.5 \%$, respectively. Basalts and zeolites are important low-cost materials for water treatment of both surface runoff and wastewater. Therefore, they have a high cation exchange capacity, which is favorable since they present a high performance in the absorption of metal contaminants that can be found in the infiltration of water in permeable pavements (Wang \& Pang, 2010).

As mentioned before, permeable concrete is a structure with the ability to reduce the volume of surface rainwater through its network of pores. In addition, permeable concrete improves water quality and helps mitigate the effects of the heat island due to the growth of the urban place (Haselbach, Boyer, Kevern, \& Schaefer, 2011). In recent research (ACI, 2010; Delatte, Mrkajic, Miller, 2009) it has been demonstrated that the use of permeable concrete allows the retention of heavy metals from surface runoff, these investigations focused on fully permeable pavement 
Tecnología y

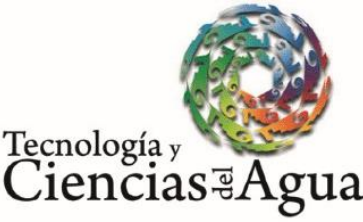

2021, Instituto Mexicano de Tecnología del Agua

Open Access bajo la licencia CC BY-NC-SA 4.0

(https://creativecommons.org/licenses/by-nc-sa/4.0/)

systems that mainly consist of common Portland cement as the binder material, coarse aggregates, aggregates fine or not fine and water (ACI, 2010; Delatte et al., 2009).

Features such as the distribution, size, and tortuousness of stone aggregates in permeable concrete can be modified. So, there is a filtration of contaminants and provide enough time for the water to interact with the $\mathrm{pH}$ [high $>12.00$ standard units $(\mathrm{S} / \mathrm{U})$ ] of a permeable concrete mixture (Komastka, Kerkhoff, \& Panarese, 2003). Many techniques such as adsorption, chemical oxidation, precipitation, solvent extraction, ion exchange, membrane processes, and reverse osmosis have been developed for the removal of metal ions from aqueous solutions (Eloussaief \& Benzina, 2010). Among them, adsorption technology is the most promising process involved in the removal of toxic metals from industrial waste streams and natural waters with the selection of a suitable adsorbent (Potgieter, Potgieter-Vermaak, \& Kalibantonga, 2006; Aydin, Bulut, \& Yerlikaya, 2008). According to the afore-mentioned researchers, permeable concrete can have high absorption capacities of heavy metals, which may contribute to improving the quality, and thus prevent water contamination due to possible leakages that the vehicle fleet spills on the roads.

In summary, the contribution of this research is justified by the development of a detailed methodology on the implementation of a natural basalt of $9.5 \mathrm{~mm}$ maximum size as aggregate in permeable concrete mixtures. The batch adsorption method is used for determining the efficiency to eliminate typical concentrations of As, Cd, and $\mathrm{Zn}$ simulating the heavy metals found by different authors in the 
accumulated sediments on the hydraulic infrastructure in low traffic roads of the highways.

\section{Materials and methods}

\section{Basaltic rock characterization}

The characterization of basaltic rocks is widely documented in the literature. For example, Borazjani, Ghiasi-Freez, and Hatampour (2016) reported that the use of petrographic thin sections is the first step to understand the characteristics of a rock. In this sense, Paulsen et al. (2013) established that thin sheets are principally used for the identification of minerals and aspects such as fractures, mineral zoning, and rock textures, as well as to concisely identify the formation of rocks and their classification. Samples of basaltic rock pieces reduced to a thickness of 30 microns $(\mu \mathrm{m})$, with their polished surfaces, were used to determine that the aggregate used in permeable concrete is a basalt. The thin sheets were observed through a petrographic microscope model MOTIC BA310, such samples are analyzed using transmitted light for the determination of mineral content, rock texture, and mineral alteration. It 
Tecnología y

Ciencias $\stackrel{\varpi}{\triangleleft}$ Agua
2021, Instituto Mexicano de Tecnología del Agua

Open Access bajo la licencia CC BY-NC-SA 4.0

(https://creativecommons.org/licenses/by-nc-sa/4.0/)

was observed that basalt is mainly composed of pyroxenes and plagioclase rich in $\mathrm{Ca}$, its texture is aphanitic and its structure is vesicular as illustrated in Figure 1.

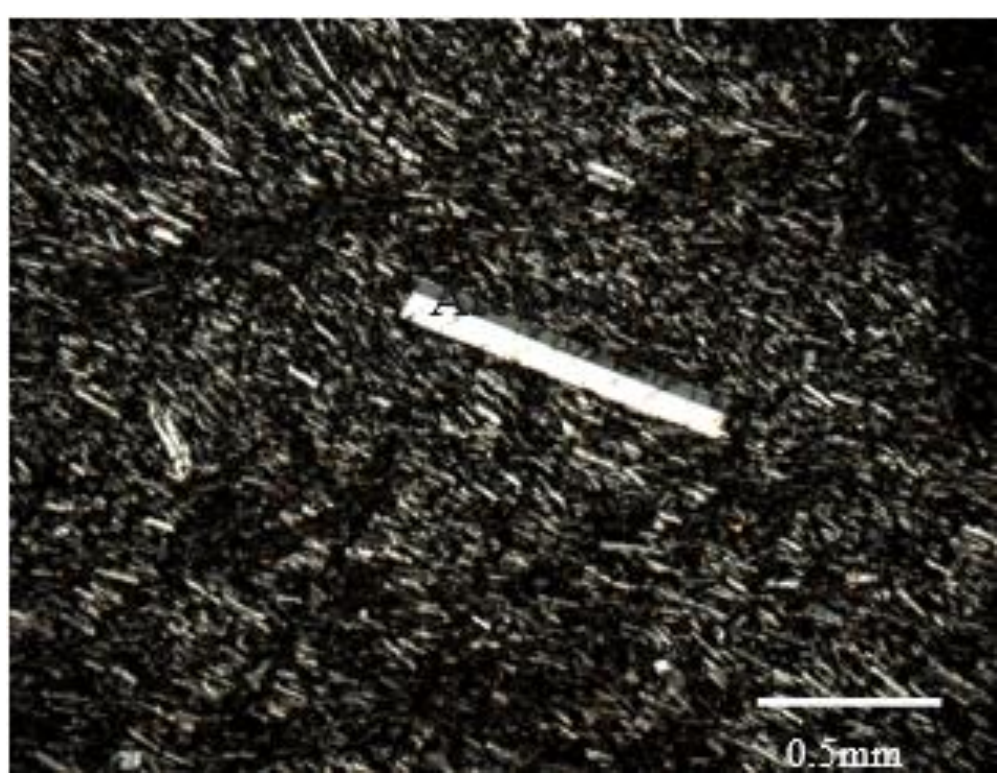

Figure 1. Microscopy of thin sections of basaltic rock at a scale of 0.5 $\mathrm{mm}$.

\section{Specimens of Permeable Concrete}

The dosage method was based on the volume of the paste required to join the aggregates and maintain the design void content according to the American Concrete Institute recommendation (ACI, 2010). Permeable 
Tecnología y

Ciencias $₫$ Agua
2021, Instituto Mexicano de Tecnología del Agua

Open Access bajo la licencia CC BY-NC-SA 4.0

(https://creativecommons.org/licenses/by-nc-sa/4.0/)

concrete cylinders were prepared using a mixture of CEMEX CP30 compound composite Portland cement, the maximum nominal aggregate size of $9.5 \mathrm{~mm}$ (obtained from the La Cañada material bank located in the city of Querétaro, Mexico), and water. Table 1 summarizes the proportions of the above-mentioned materials used in $1 \mathrm{~m}^{3}$ of the mixture. Such materials were combined in a concrete mixer and sneaked into cylindrical molds.

Table 1. Proportion of the permeable concrete mixture.

\begin{tabular}{|l|l|l|}
\hline Material & Quantity & Units \\
\hline Cement & 320.57 & $\mathrm{~kg} / \mathrm{m}^{3}$ \\
\hline Thick Aggregate & 1679.153 & $\mathrm{~kg} / \mathrm{m}^{3}$ \\
\hline Effective water & 128.08 & $\mathrm{~kg} / \mathrm{m}^{3}$ \\
\hline
\end{tabular}

Once mixed, the cylinders were covered and cured for 7 days in a controlled environmental chamber with $50 \%$ humidity at $23^{\circ} \mathrm{C}$, before testing the absorption batches. The dimensions of the cylinders were $50 \times 100 \mathrm{~mm}$. Tests were conducted to determine the compressive strength of cylindrical specimens of permeable concrete according to ASTM C39 as shown in Figure 2 and shown in the lines below in Table 5 (ASTM, 2015). To decrease the experimental variability, every cylinder was prepared in the same batch of concrete using similar sources of cement and aggregates. The process of the test was designed to determine if the permeable concrete may be able to eliminate heavy 
metals and measure the level of retention that concrete may have at different initial concentrations of As, Cd and Zn.

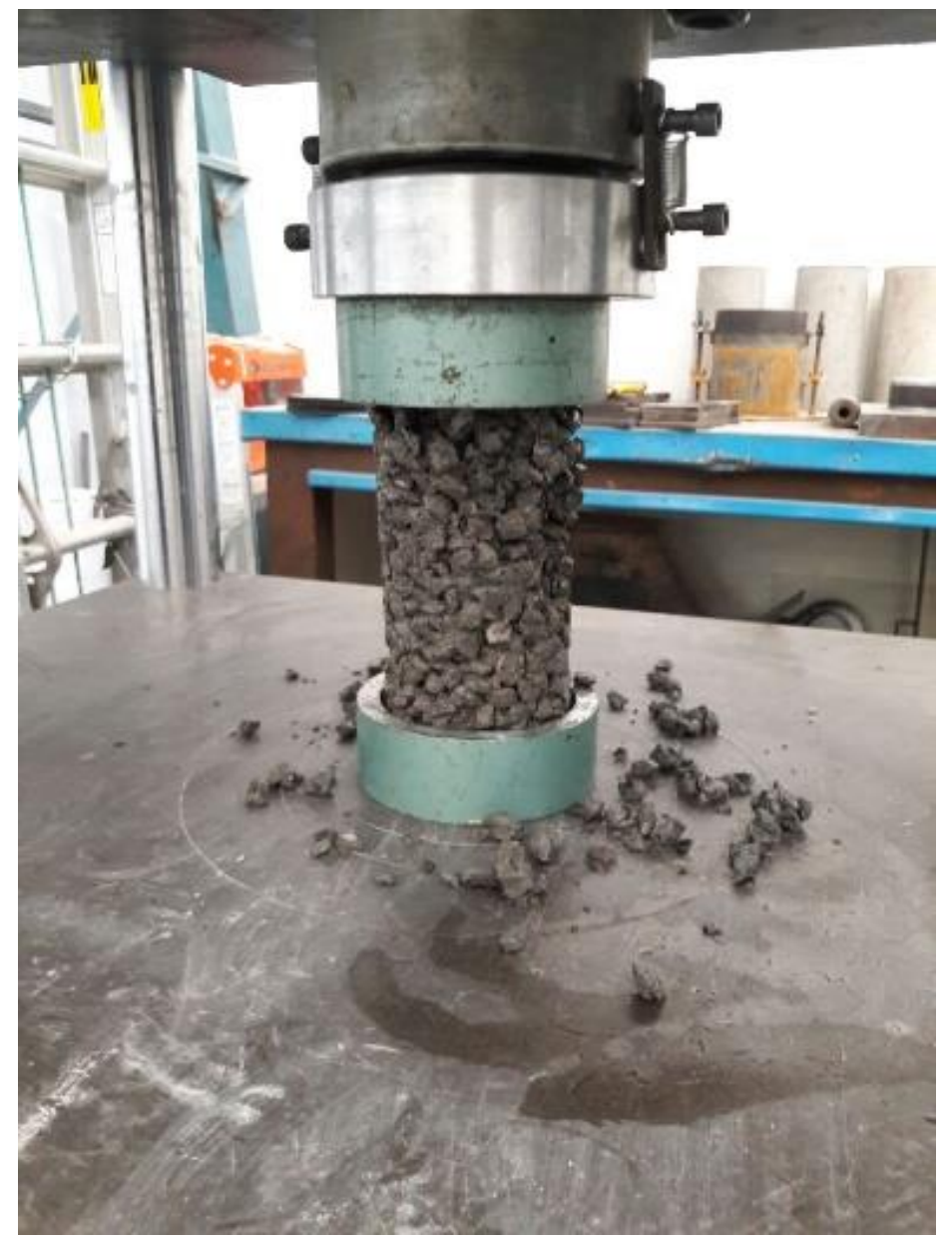

Figure 2. Simple compression Permeable concrete cylinders.

\section{Batch absorption method}


Three solutions were prepared with standard reagents of As, Cd, and $\mathrm{Zn}$ (ASTM, 2015). The standard solutions had a concentration of $1000 \mathrm{mg} \mathrm{I-}$ 1. From each standard solution, dilutions were made to obtain uniform concentrations of $\mathrm{Cd}$ and $\mathrm{Zn}$ of $10,30,50$, and $90 \mathrm{mg} / \mathrm{l}$, respectively for each contaminant. This batch test was performed by immersing the concrete cylinders in a 1-L beaker containing the solutions of As, Cd and $\mathrm{Zn}$ for $96 \mathrm{~h}$. All beakers were washed with acid in a $5 \%$ nitric acid solution for $12 \mathrm{~h}$ and rinsed with distilled water before the test (see Figure 3 ).

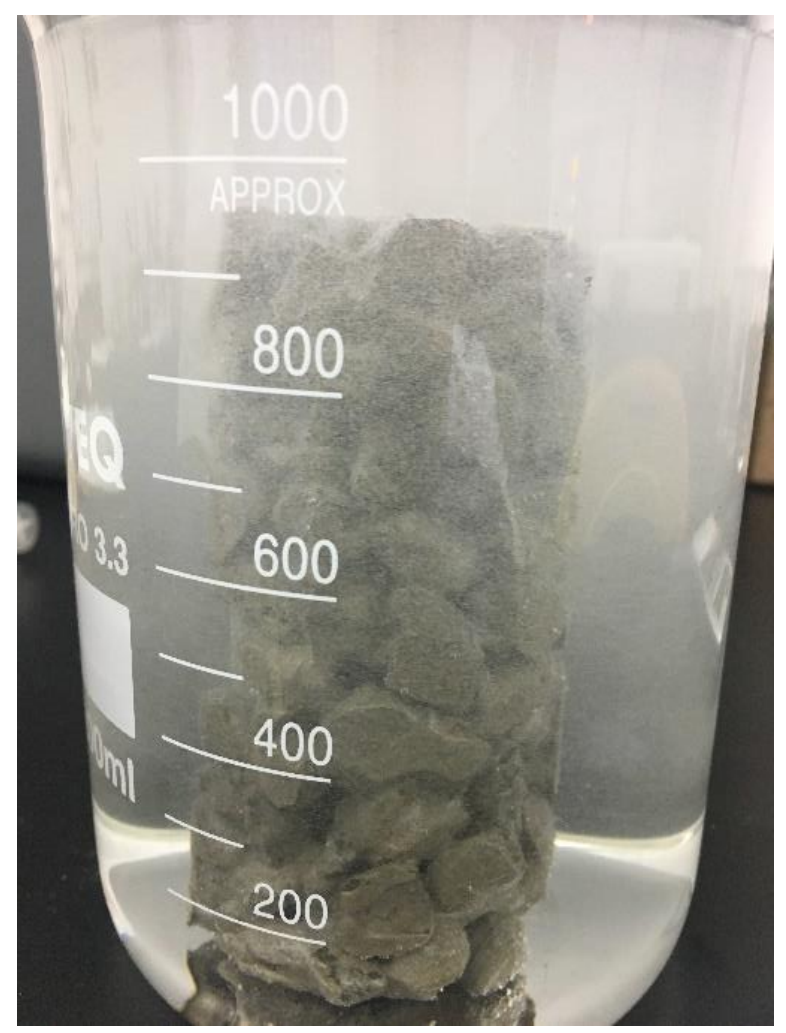

Figure 3. Deposition of heavy metal precipitates in concrete in a batch reactor. 
After $96 \mathrm{~h}$, the concrete cylinders were removed from the solution, drip-dried, lightly covered by a cellulose-based plastic wrap, and finally dried inside the environmental chamber at $50 \%$ humidity at $23{ }^{\circ} \mathrm{C}$. To avoid cracking and preserve surface reactions, the analysis was subsequently performed on the total reflection $\mathrm{X}$-ray fluorescence spectrometer (TXRF).

\section{Total Reflection X-Ray Fluorescence (TXRF)}

In this investigation, a TRFX spectrometer (S2 PICOFOX, "Buker" AXS Microanalysis $\mathrm{GmbH}$ ) was used. The instrument calibration was improved with a standard of chemical elements concentration used in this research such as As, Cr, Cd, and $\mathrm{Zn}$ of $1 \mathrm{mg} / \mathrm{l}$. The time for data acquisition for each sample during the calibration process was 1000 s. Each spectrum was analyzed. This device has a low-power X-ray ceramic metal tube cooled with a molybdenum lens, working at a maximum power of $50 \mathrm{~W}$, and a silicon drift detector (SDD) without liquid nitrogen with the compact S2 PICOFOX TXRF instrument (Bruker, 2007). The technical specifications according to the Bruker manufacturer of the S2 PICOFOX TXRF instrument are summarized in Table 2. 
Table 2. S2 PICOFOX technical specifications.

\begin{tabular}{|l|l|}
\hline \multicolumn{1}{|c|}{ Technical specification } & \multicolumn{1}{c|}{ Unit } \\
\hline X-ray tube & $50 \mathrm{~W}(50 \mathrm{kV}, 1 \mathrm{~mA})$, Mo objective \\
\hline Optics & Multilayer monochromator, $17.5 \mathrm{KeV}$ \\
\hline Detector area & $10 \mathrm{~mm}^{2}, \sim 140 \mathrm{eV} @ \mathrm{Ka}-\mathrm{Mn}$ \\
\hline Carrier Quartz & $30 \mathrm{~mm}$ diameter \\
\hline Size, weight & $590 \times 450 \times 300 \mathrm{~mm}, 37 \mathrm{~kg}$ \\
\hline
\end{tabular}

\section{Sample Preparation for Total Reflection X-Ray Fluorescence Analysis}

Polished spectrosil (synthetic) quartz discs have $30 \mathrm{~mm}$ in diameter and $3.0 \mathrm{~mm}$ of thickness. They were used for sample preparation. Before starting the test, a cleaning protocol was followed, comprising several stages. First, a cleaning solution RBS 50TM (SigmaTM, Germany) 5:50 to ultrapure water (18 $\mathrm{M} \Omega \mathrm{cm}$, Milli-Q, Millipore) was used. Then, nitric acid solution at $10 \%$ under heating, rinsing with ultrapure water, drying in an oven at $80^{\circ} \mathrm{C}$ was applied. Finally, the siliconization of the surface was performed with a solution of silicon in isopropanol (ServaTM, Germany) so that the surface becomes hydrophobic and causes a small evaporation point. The successful removal of the previous sample was verified by 
carrying out blank test measurements, the absence of element peaks, apart from silicon (Si), quartz, and molybdenum (Mo) from the source was observed. Figure 4 illustrates the process of preparation for TXRF analysis samples, where Figure 4(a) shows the addition of silicone in isopropanol and Figure 4(b) illustrates the preparation of the sample including $10 \mu \mathrm{L}$ solution of the concrete sample exposed to Arsenic, Zinc and Cadmium metals for TXRF analysis.

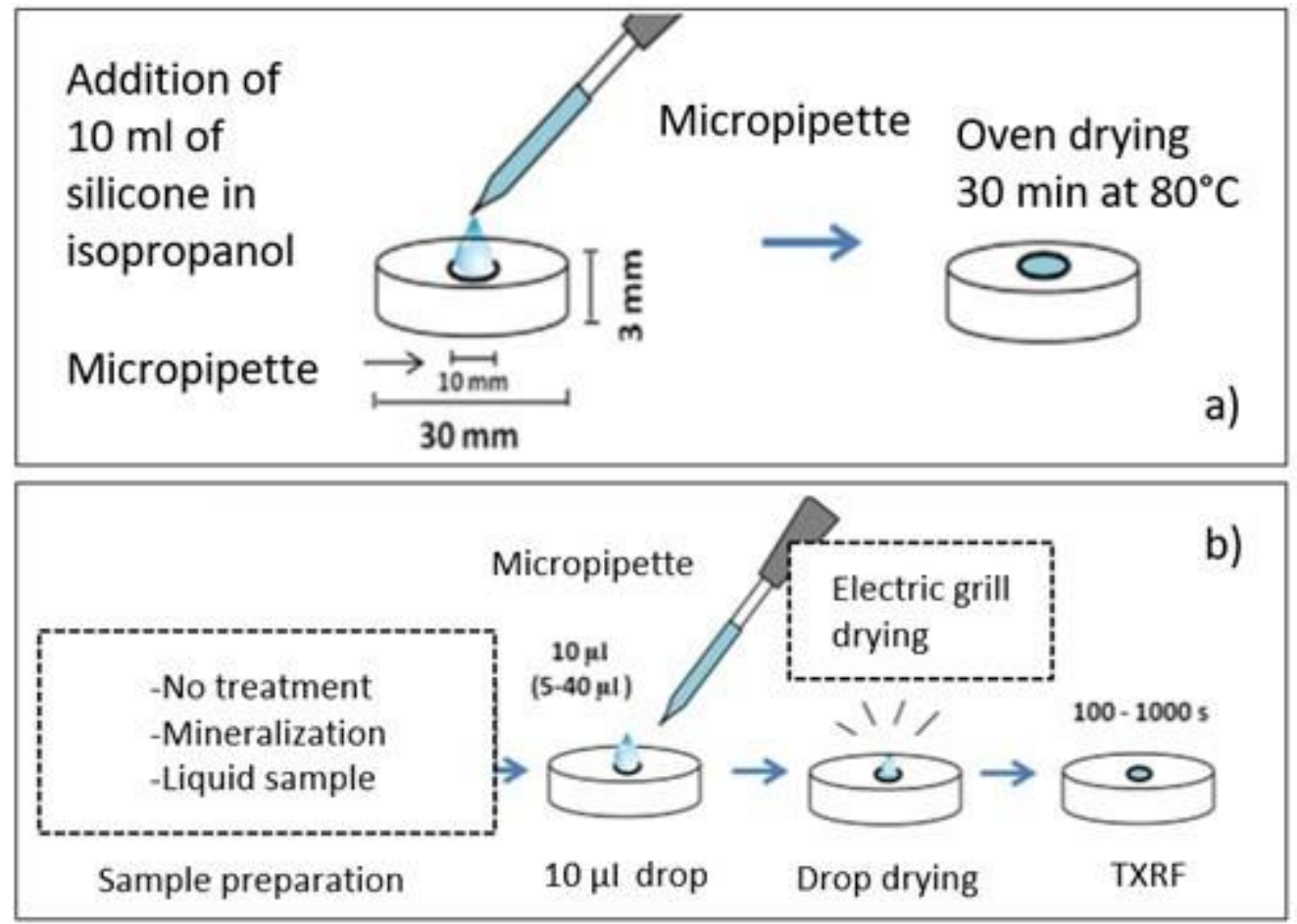

Figure 4. Preparation of the samples for analysis with S2 PICOFOX: (a) Addition of silicone in isopropanol Y; (b) sample preparation for TXRF analysis (De-La-Calle, Cabaleiro, Romero, Lavilla, \& Bendicho, 2013). 
Finally, the quantitative analysis was performed by internal standardization of the analysis samples. Gallium was chosen as the internal standard due to its low abundance in the type of samples studied and good sensitivity in the determination of TXRF.

\section{Total Reflection X-Ray Fluorescence Measurements}

The instrument calibration test was performed with a multi-element standard containing a certified concentration of $\mathrm{Ar}, \mathrm{Cr}, \mathrm{Cd}, \mathrm{Zn}$, and $\mathrm{Mr}$ of $1 \mathrm{mg} / \mathrm{l}$ (Bruker, 2011). The data acquisition time for each sample measurement was $1000 \mathrm{~s}$ (live time). The spectra were processed with the S2 PicofoxTM software (Bruker, 2011). Subsequently, the lines of the elements to be found in the response spectrum are identified to verify which elements are in the sample to be analyzed. Finally, the concentration of the elements was calculated from Eq. (1) using the intensities and relative sensitivities of the elements to be analyzed, which are dimensionless values that indicate the maximum intensities of the respective elements about the quantity of sample (Bruker, 2011).

$C_{i}=\frac{C_{I S} * N_{i} * S_{I S}}{N_{I S} * S_{i}}$ 
Where $\mathrm{Ci}$ is the concentration of the element to be analyzed; CIS is the concentration of the internal standard; $N_{i}$ is the number of the net pulse within the measurement spectrum of the element to be analyzed; $N_{I S}$ the number of the net pulse within the measurement spectrum of the internal standard; $S_{i}$ the relative sensitivity of element $i$; $S_{I S}$ is the relative sensitivity of the internal standard element.

\section{Energy-dispersive X-ray Fluoresce (EDXRF)}

A commercially available benchtop EDXRF spectrometer (S2 PUMA Carousel, Bruker AXS, MbH, Germany) was used in the present study. This instrument is equipped with a Pd target $\mathrm{X} X$-ray tube (max. Power 50 W) and a XFLASH LE Silicon Drift Detector (SDD), ultra-thin beryllium window (0.3 $\mu \mathrm{m}$ thickness) with a resolution lower than $129 \mathrm{eV}$ at $\mathrm{Mn}-\mathrm{Ka}$ line for a count rate of 100,000 counts-per second. In this LE configuration of SDD detectors, the intensities for $\mathrm{Na} \mathrm{K}$-alpha and $\mathrm{Mg} \mathrm{K}$-alpha are, respectively close to 8 and 4 times higher than the intensity recorded by conventional SDD detectors. The instrument is also equipped with nine primary filters that can be used in front of the tube before the X-ray beam impinges the sample surface to improve measuring conditions for the elements of interest and it can operate under vacuum conditions. The technical specifications according to the Bruker manufacturer of the S2 PUMA EDXRF instrument are summarized in Table 3. 
Table 3. S2 PUMA technical specifications.

\begin{tabular}{|c|c|}
\hline Technical specification & Unit \\
\hline Range of elements & Sodium to Uranium ( $\mathrm{Na}-\mathrm{U})$ \\
\hline Range of concentration & From $\mathrm{mg} \mathrm{l}-1$ to $100 \%$ \\
\hline Anode X-ray tube & $\begin{array}{l}\text { Pd; power max 50; voltage max. } 50 \\
\text { kV }\end{array}$ \\
\hline Primary filter & $10 \mathrm{~mm}^{2}, \sim 140 \mathrm{eV} @ \mathrm{Ka}-\mathrm{Mn}$ \\
\hline Sample Size & $\begin{array}{l}\text { Samples of } 32.40 \text { or } 51.5 \mathrm{~mm} \varnothing \\
(1.26,1.56 \text { or } 2.03 \text { inch). Large } \\
\text { Samples: max width } 457 \mathrm{~mm}(18.00 \\
\text { inch). }\end{array}$ \\
\hline Sample Loader & $\begin{array}{l}\text { EasyLoad }^{\mathrm{TM}} \text { Carousel sample tray, } 12 \\
\text { positions, removable }\end{array}$ \\
\hline Size & $\begin{array}{l}66 \times 70 \times 56 \mathrm{~cm} ; 127 \mathrm{~kg} \\
26 \times 27.6 \times 22.0 \text { inch; } 278 \mathrm{lbs}\end{array}$ \\
\hline Kind of samples & $\begin{array}{l}\text { Loose powders, granules, solids, } \\
\text { pressed pellets, molten pearls, and } \\
\text { liquids up to } 50 \mathrm{ml}\end{array}$ \\
\hline
\end{tabular}

The software used to control the equipment, build the calibrations, and perform the data treatment was SPECTRA EDX (Bruker AXS, GmbH, Germany). Such software can perform the full line profile fitting, 
Tecnología y

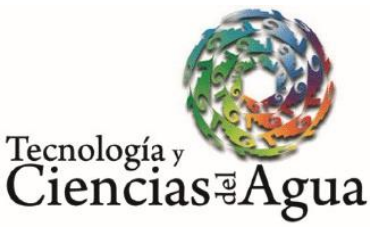

2021, Instituto Mexicano de Tecnología del Agua

Open Access bajo la licencia CC BY-NC-SA 4.0

(https://creativecommons.org/licenses/by-nc-sa/4.0/)

deconvolutions when lines overlap, intensity corrections for inter-element effects, and full-quantitative routines.

\section{Arsenic absorption lots with permeable concrete and concentration measurement with spectrometry (EDXRF)}

The preparation of concrete and basalt specimens followed a methodology similar to that of thin sheets for petrography. First, the manufacture of concrete cubes was carried out with the proportion of the mix design for permeable concrete, except that, without the added basalt stone, this was to be able to perform the analysis separately for concrete and basalt. A cutter of MK-500 material was used to give the samples a regular shape. Once the solution was prepared at a concentration of $90 \mathrm{mg} \mathrm{I-1}$ of As in water, the suspension of concrete samples of $5 \mathrm{~cm} \times 5 \mathrm{~cm}$ sideways with a thickness of $5 \mathrm{~mm}$ and basalt with measurements of $3 \mathrm{~cm} \times 2 \mathrm{~cm}$ was taken, in Falcon centrifuge tubes up to a height of $10 \mathrm{ml}$ of As solution. The test time was 8 days at a constant temperature of $25^{\circ} \mathrm{C}$ in an oven. After 8 days, the samples were removed from the solution, to subsequently perform the analysis on the S2 PUMA spectrometer with the EDXRF technique. Sampling was performed at 2, 4, 6, and 8 days, respectively for both liquid basalt and concrete samples. The solid samples were dried in the oven at a temperature of $25^{\circ} \mathrm{C}$ for $24 \mathrm{~h}$ before 
Tecnología y

Ciencias đAgua
2021, Instituto Mexicano de Tecnología del Agua

Open Access bajo la licencia CC BY-NC-SA 4.0

(https://creativecommons.org/licenses/by-nc-sa/4.0/)

taking their measurement. For the liquid samples, the process was different, since for its preparation plastic cups were used to store $7.0 \mathrm{~g}$ of liquid sample already contaminated with As, at the bottom of this glass a transparent Mylar membrane was used. After 8 days of taking and preparing the samples, all samples were measured. For this, a Bruker S2 PUMA brand device was used to measure up to 11 samples. Plastic cups containing liquid samples were placed in the equipment carousel. Once all the samples were mounted on the S2 PUMA, the type of sample (solid or liquid) and the characteristics of the sample are selected. The sample ID was introduced, then the diameter of $3.5 \mathrm{~cm}$ of the plastic cup, with a Myler membrane with a thickness of 3.60 microns $(\mu \mathrm{m})$, to then perform the quantification with the equipment with a duration of 5 minutes per sample. The response spectrum of the equipment is shown in Figure 5.

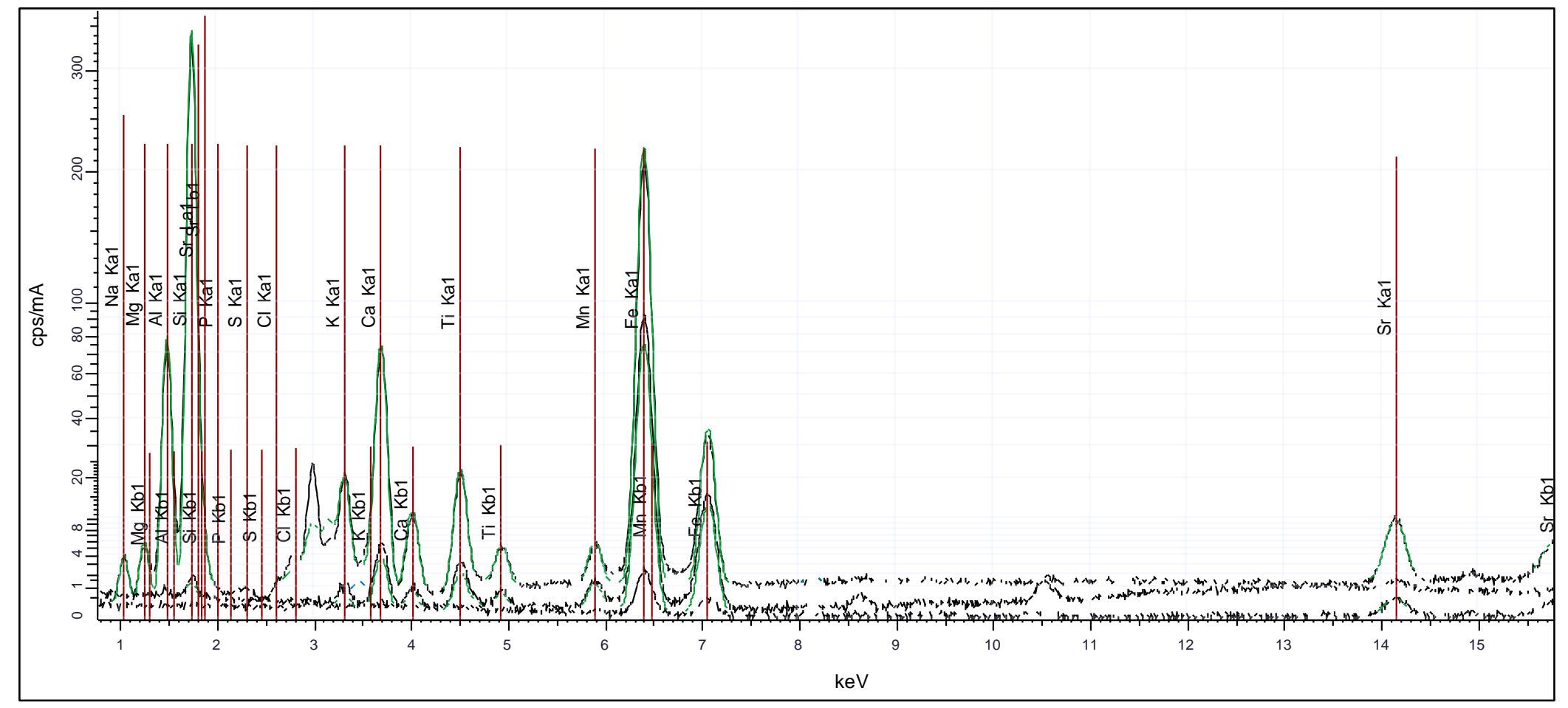


Figure 5. Response spectrum for As $90 \mathrm{mg} \mathrm{I-1}$ solution.

\section{Results and discussion}

\section{Permeable Concrete Mix Design for Contaminant Absorption Tests}

A mixture of simple permeable concrete containing a coarse aggregate of basaltic stone, composite Portland cement, and water was used for the experiment. The maximum nominal size of the aggregate was $9.5 \mathrm{~mm}$ $\left(3 / 8^{\prime \prime}\right)$. The specific gravity of the aggregate was 2.90 , and the absorption was $1.5 \%$ (ASTM, 2015). All mixtures were designed for empty spaces of $20 \%$ and were produced with a water-cement ratio of 0.40 . Table 4 summarizes the mechanical properties of basalt used in the permeable concrete mixture.

Table 4. Basalt mechanical properties.

\section{Basalt mechanical properties $\left(\mathrm{kg} / \mathrm{m}^{3}\right)$}




\begin{tabular}{|l|c|}
\hline Compact dry volumetric mass & 1.44 \\
\hline Loose-dry volumetric mass & 1.53 \\
\hline Apparent specific weight & 2.81 \\
\hline Apparent specific weight (S.S.S) & 2.85 \\
\hline Nominal specific weight & 2.94 \\
\hline$\%$ absorption & 1.58 \\
\hline
\end{tabular}

Additional information about the resistance of the samples of concrete used in this research is presented in Table 5.

Table 5. Simple compression values of permeable concrete cylinders.

\begin{tabular}{|c|c|c|c|c|}
\hline $\begin{array}{c}\text { Age } \\
\text { (days) }\end{array}$ & $\begin{array}{c}\text { Cylinder } 1 \\
\text { resistance } \\
(\mathbf{k g})\end{array}$ & $\begin{array}{c}\text { Cylinder } 2 \\
\text { resistance } \\
(\mathbf{k g})\end{array}$ & $\begin{array}{c}\text { Cylinder } 3 \\
\text { resistance } \\
(\mathbf{k g})\end{array}$ & $\begin{array}{c}\text { Average } \\
\text { resistance } \\
\left(\mathbf{k g} / \mathrm{cm}^{2}\right)\end{array}$ \\
\hline 7 & 108.68 & 107.52 & 109.68 & 108.63 \\
\hline 14 & 126.89 & 125.68 & 127.63 & 126.73 \\
\hline 21 & 153.48 & 151.36 & 154.87 & 153.24 \\
\hline 28 & 177.69 & 178.69 & 181.65 & 179.34 \\
\hline
\end{tabular}

The results obtained are within the expected range of $140 \mathrm{~kg} / \mathrm{cm} 2$ to $180 \mathrm{~kg} / \mathrm{cm} 2$ after 28 days of setting (ACI-522R.6, 2006), which are appropriate for the use of this permeable concrete as drainage infrastructure on a land route, or streets or roads with little traffic. 


\section{Heavy metal retention with permeable concrete}

This study has been carried out to determine the efficiency of As, Zn, and Cd removal from the synthetic aqueous solution using permeable concrete with basaltic rocks. For batch tests with permeable concrete, the removal efficiencies were as follows: As 55-81 \%, Zn $75 \%-96 \%$, and Cd 50-89 $\%$. As the concentration of metals increased, retention efficiencies decreased, except for $\mathrm{Cd}$, which had better disposal levels at a higher concentration. The percentage of removal of individual heavy metals for each solution is shown in Figure 6. On the other hand, Figure 7 and Figure 8 are grouped by initial concentration, final concentration, and efficiency percentage. In general, all samples showed high levels of metal removal. For concentrations less than $10 \mathrm{mg} / \mathrm{l}$ of $\mathrm{As}$ and $\mathrm{Zn}$, it is observed a higher absorption efficiency, and for concentrations greater than $10 \mathrm{mg} / \mathrm{l} \mathrm{Cd}$, higher levels of heavy metal retention are noted. 


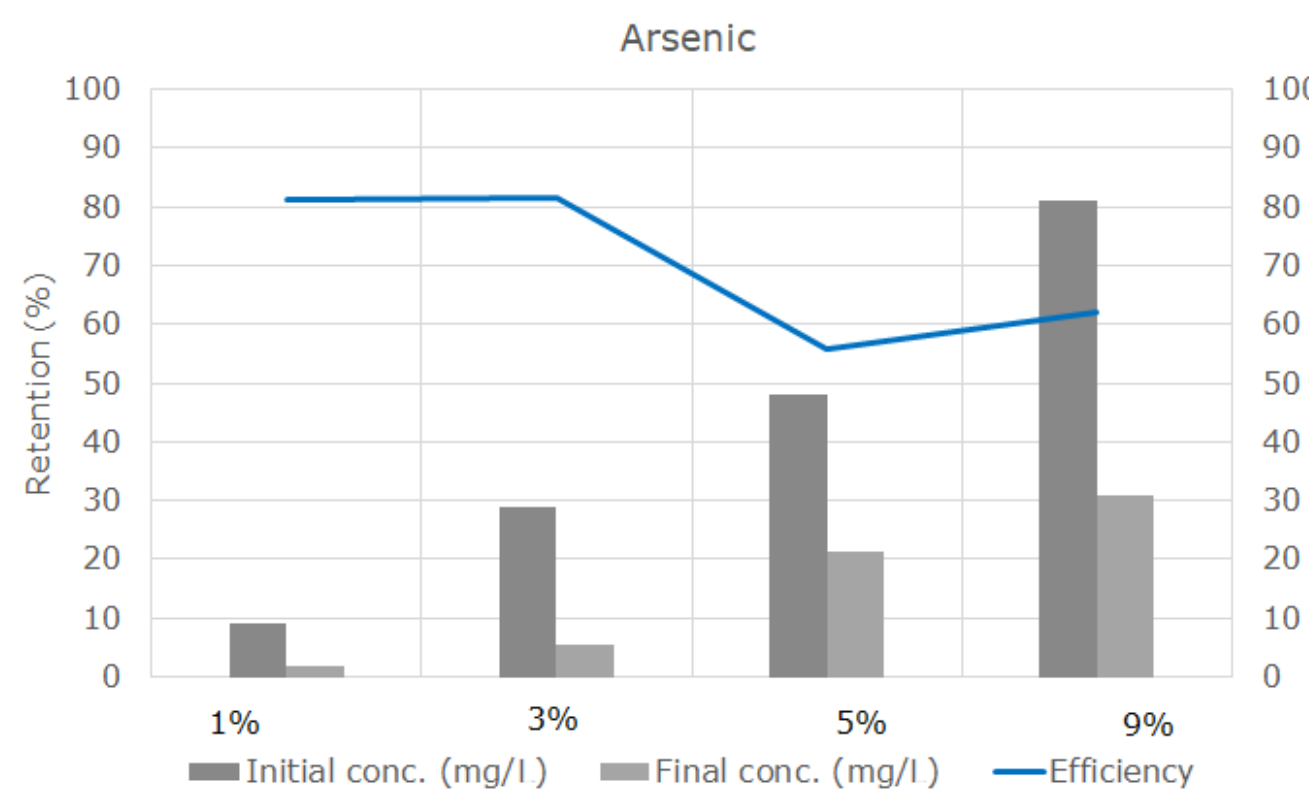

Figure 6. Arsenic retention efficiency with the use of permeable concrete. 


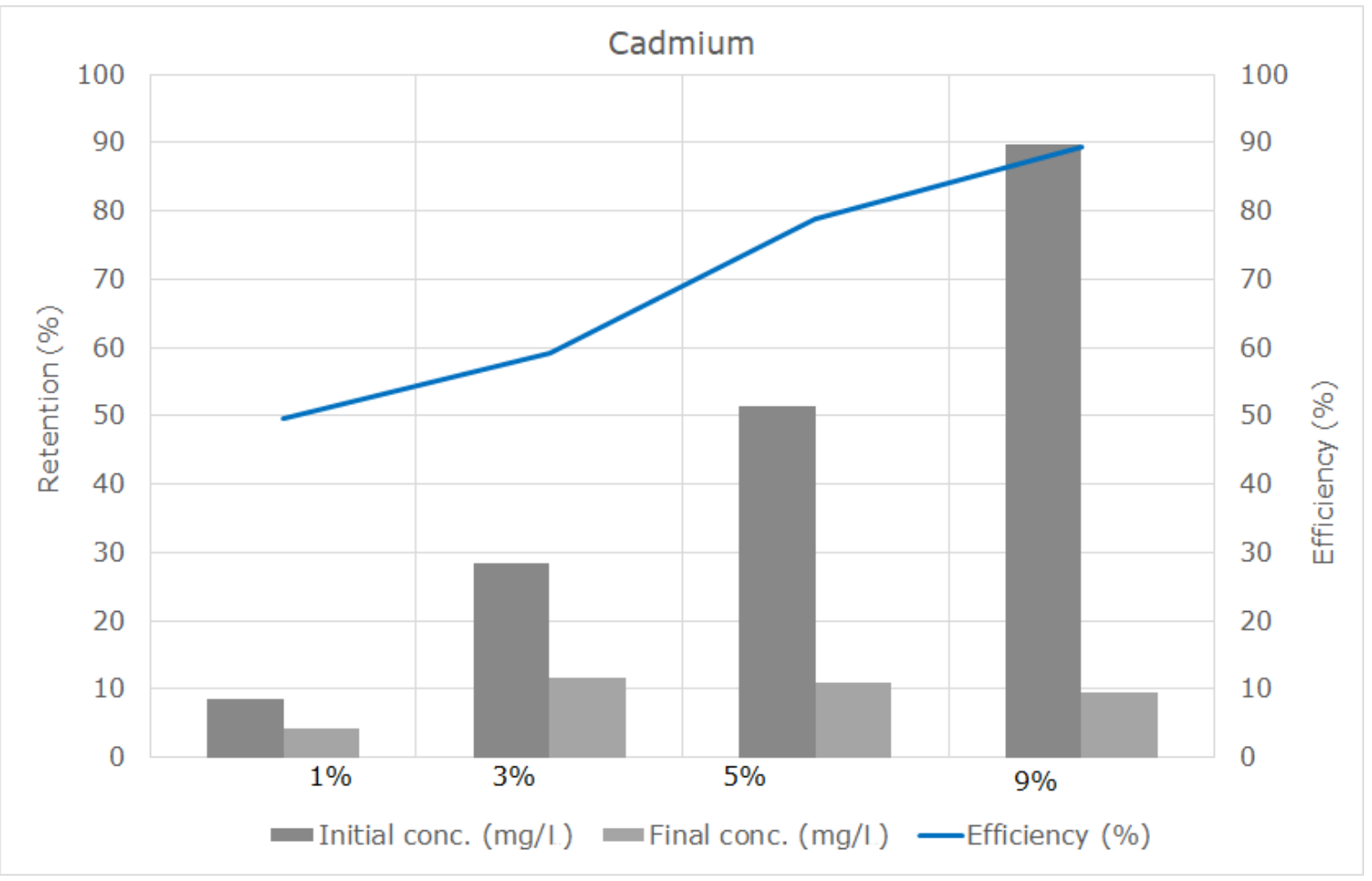

Figure 7. Cadmium retention efficiency with the use of permeable concrete. 


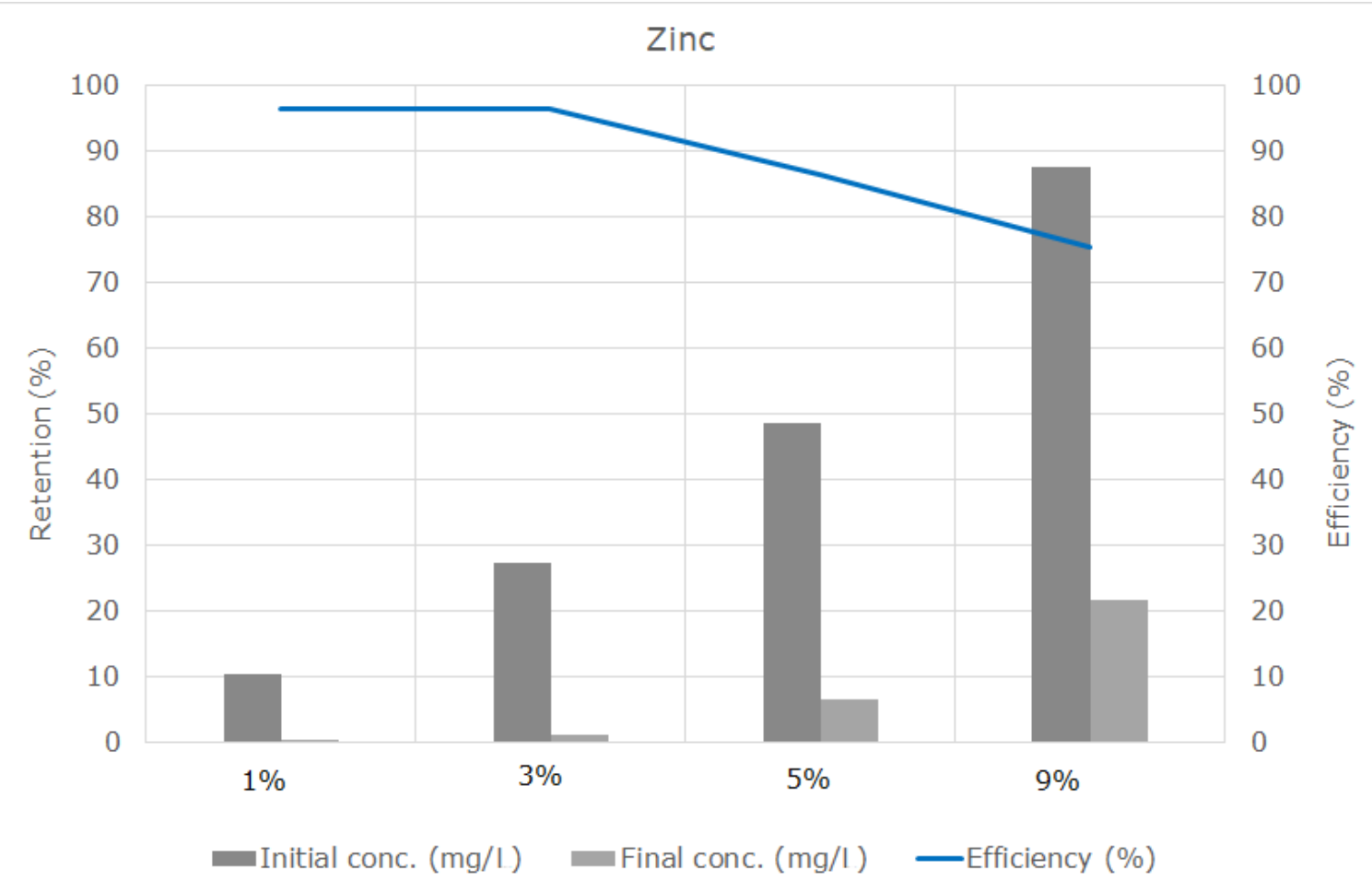

Figure 8. Zinc retention efficiency with the use of permeable concrete.

Other elements that were found in the measurement of the solutions with the total reflection X-ray fluorescence method and the S2 PICOFOX equipment are presented in Table 6.

Table 6. The initial and final concentration of other elements found in the solutions.

\begin{tabular}{|c|c|c|c|c|c|c|c|c|c|}
\hline \multirow{2}{*}{} & \multicolumn{7}{|c|}{ Concentration S2PICOFOX (mg/I) } \\
\cline { 2 - 9 } & $\begin{array}{c}\text { Initial } \\
(1 \%)\end{array}$ & $\begin{array}{c}\text { Final }(1 \\
\%)\end{array}$ & $\begin{array}{c}\text { Initial } \\
(3 \%)\end{array}$ & $\begin{array}{c}\text { Final } \\
(3 \%)\end{array}$ & $\begin{array}{c}\text { Initial } \\
(5 \%)\end{array}$ & $\begin{array}{c}\text { Final } \\
(5 \%)\end{array}$ & $\begin{array}{c}\text { Initial } \\
(9 \%)\end{array}$ & $\begin{array}{c}\text { Final }(9 \\
\%)\end{array}$ \\
\hline Arsenic & $\begin{array}{c}\text { Phosphorus } \\
(P)\end{array}$ & 58.75 & 72.20 & 76.17 & 135.93 & 84.38 & 94.13 & 79.76 & 90.96 \\
\hline
\end{tabular}


2021, Instituto Mexicano de Tecnología del Agua Open Access bajo la licencia CCBY-NC-SA 4.0

Ciencias $\stackrel{\Xi}{\triangle}$ Agua (https://creativecommons.org/licenses/by-nc-sa/4.0/)

\begin{tabular}{|c|c|c|c|c|c|c|c|c|c|}
\hline & $\begin{array}{c}\text { Potassium } \\
(\mathrm{K})\end{array}$ & 11.34 & 38.25 & 12.97 & 22.99 & 12.79 & 45.00 & 11.56 & 35.38 \\
\hline & $\begin{array}{c}\text { Calcium } \\
\text { (Ca) }\end{array}$ & 50.90 & 120.05 & 57.17 & 189.59 & 58.32 & 599.20 & 51.50 & 1020.80 \\
\hline & $\begin{array}{c}\text { Chlorine } \\
\text { (Cl) }\end{array}$ & 72.77 & 25.350 & 70.54 & 64.31 & 103.12 & 165.28 & 327.80 & 409.82 \\
\hline Zinc & $\begin{array}{c}\text { Potassium } \\
\text { (K) }\end{array}$ & 52.45 & 12.817 & 9.15 & 51.78 & 11.04 & 37.63 & 18.95 & 30.48 \\
\hline & $\begin{array}{c}\text { Calcium } \\
\text { (Ca) }\end{array}$ & 60.64 & 56.710 & 62.01 & 83.66 & 53.25 & 147.18 & 90.35 & 303.41 \\
\hline & $\begin{array}{c}\text { Phosphorus } \\
\text { (P) }\end{array}$ & 46.55 & 67.450 & 61.32 & 60.02 & 46.53 & 62.63 & 46.53 & 72.59 \\
\hline Cadmium & $\begin{array}{c}\text { Potassium } \\
(\mathrm{K})\end{array}$ & 9.74 & 58.290 & 10.82 & 41.34 & 10.95 & 34.80 & 10.95 & 32.89 \\
\hline & $\begin{array}{l}\text { Calcium } \\
\text { (Ca) }\end{array}$ & 46.38 & 199.590 & 55.06 & 93.72 & 52.16 & 228.60 & 52.16 & 348.46 \\
\hline
\end{tabular}

Based on the previously presented results, $\mathrm{Zn}, \mathrm{As}$, and $\mathrm{Cd}$ are attracted by potassium, calcium, and phosphorus, which causes ionic exchange between these elements. It was also observed that there was a process of decalcification of the permeable concrete caused by the presence of As, Zn, and $\mathrm{Cd}$ in the solution, leaving basalt exposed in some areas of the cylinder. In this sense, Figure 9 illustrates this phenomenon after exposing the concrete cylinder for $96 \mathrm{~h}$ with heavy metals. 
2021, Instituto Mexicano de Tecnología del Agua

Open Access bajo la licencia CCBY-NC-SA 4.0

Tecnología y

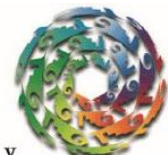

gua

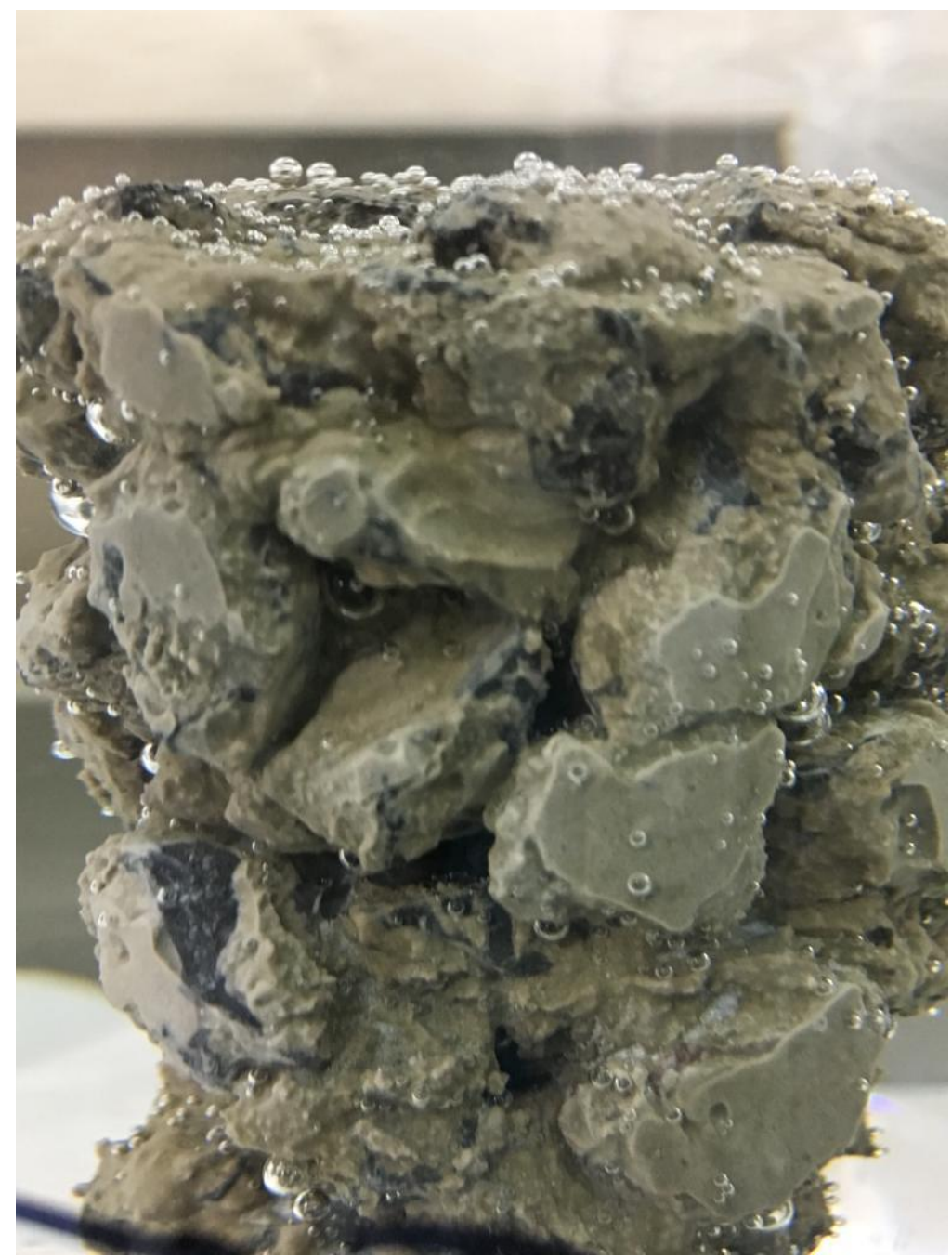

Figure 9. Decalcification of permeable concrete exposed to As, Cd, and $\mathrm{Zn}$.

Subsequently, when analyzing each contaminant separately, a general mixture was made with $\mathrm{Cd}, \mathrm{As}$, and $\mathrm{Zn}$ in the percentages where the highest retention efficiency was obtained for each of them. Next, Table 7 shows the initial and final concentrations of the elements found in the complete mixture of all contaminants. 
Table 7. Initial and final concentrations of $\mathrm{Cd}, \mathrm{Zn}$ and $\mathrm{As}$ in the As absorption batches.

\begin{tabular}{|c|c|c|}
\hline Chemical element & Initial & Final \\
\hline $\mathrm{K}$ & 9.16 & 373.90 \\
\hline $\mathrm{Ca}$ & 47.19 & 3439.92 \\
\hline $\mathrm{Zn}$ & 8.41 & 4.19 \\
\hline Ga (IS) & 10.00 & 10.00 \\
\hline $\mathrm{As}$ & 23.25 & 5.98 \\
\hline $\mathrm{Cd}$ & 79.20 & 33.34 \\
\hline
\end{tabular}

As well as what was mentioned by Zhao and Zhao (2014), where the analysis is performed for the eficence of lead and zinc removal of basalt materials, Limestone and limestone with basalt, it is determined that basalt can retain up to $80.50 \%$ Zinc, which for analysis performed for this research was up to $96 \%$, thus increasing the retention for Zinc by $15.50 \%$.

\section{Arsenic absorption lots with concrete and basalt with concentration measurement with spectrometry (EDXRF)}


After the eight days of proof of exposure of the material to the solution with As for concrete and basalt and after performing the measurements with the S2 PUMA equipment, it was verified that the calculation of the solution for $90 \mathrm{mg} \mathrm{l}-1$ of As was correct and thus to obtain the initial concentration with which reference was made to know the efficiency of each of the materials. The measured concentrations for each of the test days are shown in next Figure 10.

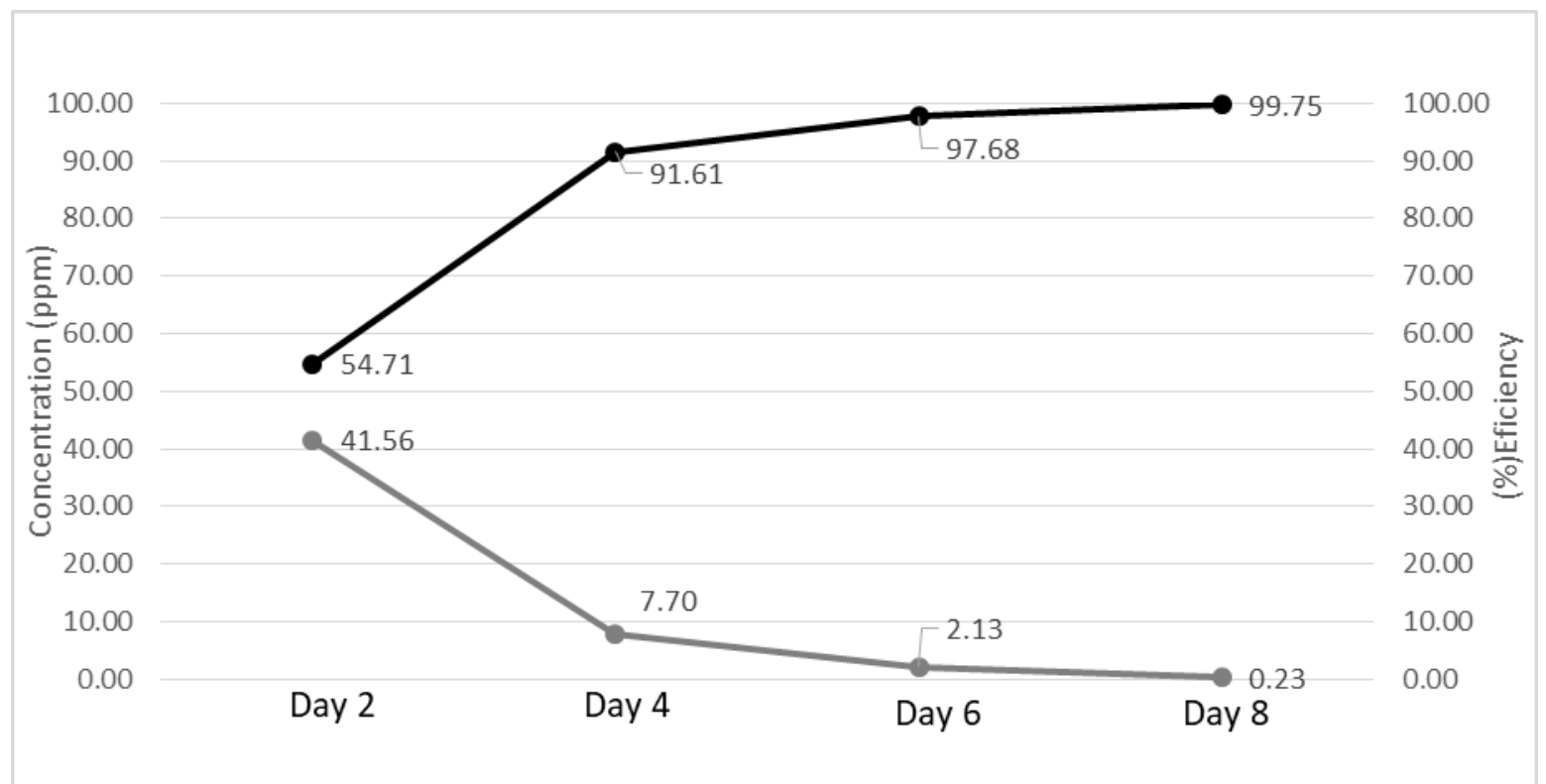

Figure 10. Measurement of arsenic concentration (lower line) and retention efficiency (upper line) with concrete.

As illustrated in Figure 10, the concrete after having been exposed to the solution with As for 8 days was able to achieve $99.75 \%$ retention, which proves that this material has excellent characteristics for the 
retention of As dissolved in water. The measurements of concentrations for basalt are shown in Figure 11.

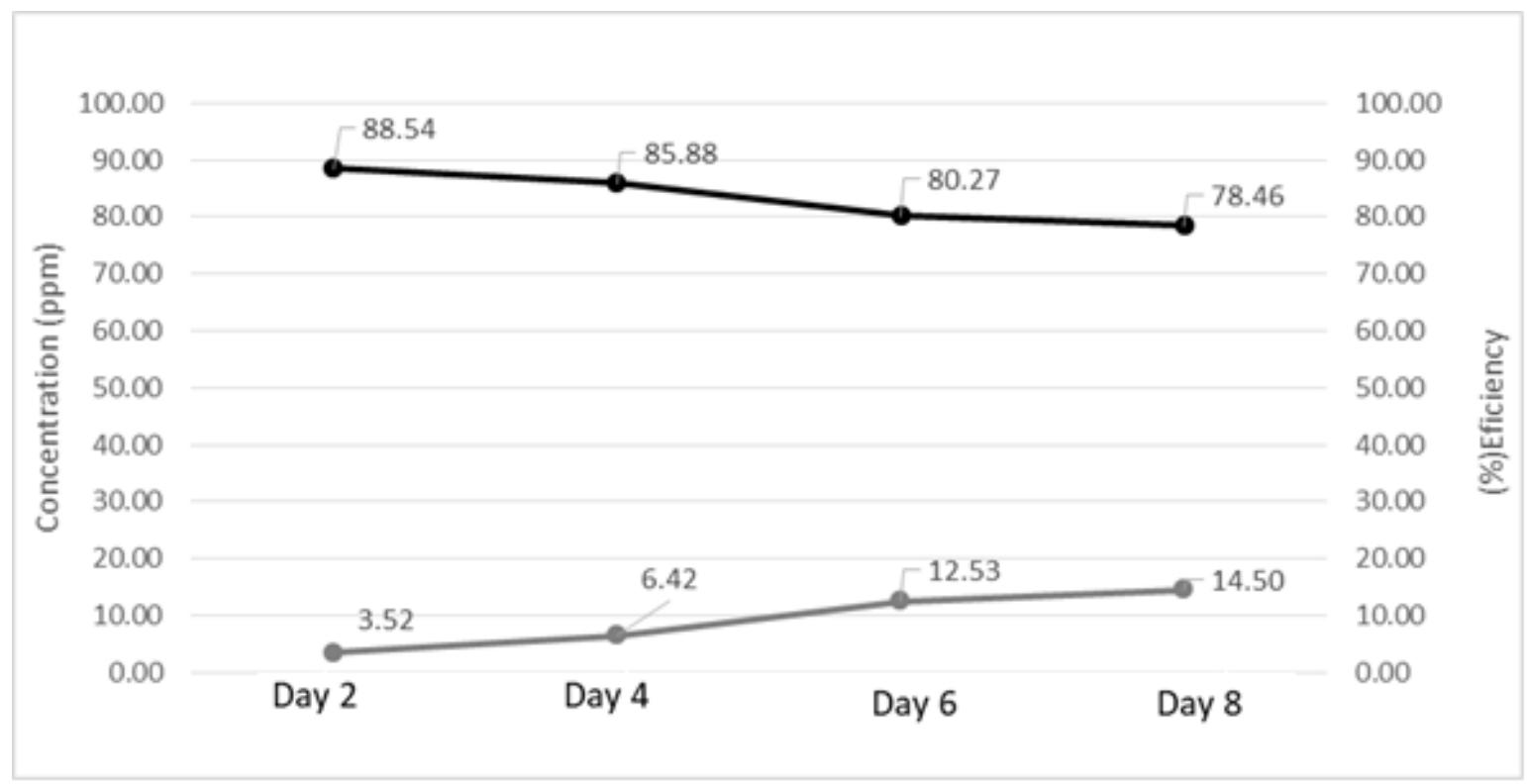

Figure 11. Measurement of arsenic concentration (lower line) and retention efficiency (upper line) with basalt.

It can be observed in Figure 10 and Figure 11 that basalt has a lower percentage of As retention concerning concrete of up to $14.50 \%$ versus $99.75 \%$ of concrete, so it can be verified that the material has higher qualities for retention is concrete.

\section{Concrete and basalt as an ion exchanger}


According to the Cemex building guidelines (Cemex, 2015), the composition for the manufacture of cement consists mainly of limestone, clay, and plaster in different proportions. With the results obtained from the analysis with the EDXRF technique, it was possible to extract the chemical composition of the cement and basalt reference before being exposed to As for 8 days. Table 8 shows the chemical composition of cement and basalt, these data were obtained with the S2 PUMA Bruker equipment.

Table 8. Chemical composition of the cement and basalt materials used.

\begin{tabular}{|c|c|c|}
\hline Composition & Concrete & Basalt \\
\hline $\mathrm{Na}_{2} \mathrm{O}$ & $0.17 \%$ & $2.94 \%$ \\
\hline $\mathrm{MgO}$ & $0.85 \%$ & $2.68 \%$ \\
\hline $\mathrm{Al}_{2} \mathrm{O}_{3}$ & $2.66 \%$ & $19.77 \%$ \\
\hline $\mathrm{SiO}_{2}$ & $15.55 \%$ & $53.18 \%$ \\
\hline $\mathrm{SO}_{4}$ & $1.18 \%$ & $0.16 \%$ \\
\hline $\mathrm{Cl}$ & $17.2002 \mathrm{mg} \mathrm{l}-1$ & $90.9707 \mathrm{mg} \mathrm{l}-1$ \\
\hline $\mathrm{K}$ & $1.54 \%$ & $1.08 \%$ \\
\hline $\mathrm{CaO}$ & $73.66 \%$ & $7.16 \%$ \\
\hline $\mathrm{MnO}$ & $0.16 \%$ & $0.18 \%$ \\
\hline $\mathrm{Fe}_{2} \mathrm{O}_{3}$ & $3.92 \%$ & $10.64 \%$ \\
\hline
\end{tabular}


Tecnología y

Ciencias $₫$ Agua
2021, Instituto Mexicano de Tecnología del Agua

Open Access bajo la licencia CCBY-NC-SA 4.0

(https://creativecommons.org/licenses/by-nc-sa/4.0/)

Specific gravity

3.15

2.81

As summarized in Table 8, concrete and basalt contain some similar chemical elements. However, some chemical compounds such as calcium oxide, which was the most released in the TXRF tests, present a higher percentage compared to basalt. In addition to this, these materials are very similar to the chemical composition that contains the Zeolites and has been more studied for use in water purification filters because of their high ion exchange capacity.

In some other investigations as the one documented by Ponce-Lira et al. (2017) it has been shown that materials containing aluminum oxide (Al2O3), ferric oxide (Fe2O3), manganese oxide ( $\mathrm{MnO}$ ), and silicon oxide (SiO2), as well as phosphates and silicates, have ion-exchange properties, these constituent elements of concrete and basalt are involved in the removal of As, Cd and $\mathrm{Zn}$ used in this investigation

The presence of calcium oxide $(\mathrm{CaO})$ in the cement, interferes with the removal of metal ions, this element directly influenced the removal of As in the concentrations used in the batch absorption test performed in this paper. In Table 9 and Table 10, the percentages obtained from the chemical composition for solid specimens of concrete and basalt are presented.

Table 9. Chemical composition of concrete when exposed to 8 days with arsenic in water.

\begin{tabular}{|l|l|l|l|l|l|}
\hline & Reference & Day 2 & Day 4 & Day 6 & Day 8 \\
\hline
\end{tabular}


Tecnología y

Ciencias $\stackrel{\unlhd}{\text { Agua }}$
2021, Instituto Mexicano de Tecnología del Agua

Open Access bajo la licencia CCBY-NC-SA 4.0

(https://creativecommons.org/licenses/by-nc-sa/4.0/)

\begin{tabular}{|c|c|c|c|c|c|}
\hline $\begin{array}{c}\text { Chemical } \\
\text { Composition }\end{array}$ & \multicolumn{5}{|c|}{ Concentration (\%) } \\
\hline $\mathrm{Na}_{2} \mathrm{O}$ & $0.17 \%$ & $0.85 \%$ & $0.78 \%$ & $0.54 \%$ & $0.47 \%$ \\
\hline $\mathrm{MgO}$ & $0.85 \%$ & $3.65 \%$ & $3.42 \%$ & $2.55 \%$ & $2.32 \%$ \\
\hline $\mathrm{Al}_{2} \mathrm{O}_{3}$ & $2.66 \%$ & $6.27 \%$ & $5.31 \%$ & $4.66 \%$ & $5.01 \%$ \\
\hline $\mathrm{SiO}_{2}$ & $15.55 \%$ & $26.59 \%$ & $25.61 \%$ & $23.60 \%$ & $22.71 \%$ \\
\hline $\mathrm{SO}_{4}$ & $1.18 \%$ & $0.70 \%$ & $0.88 \%$ & $0.96 \%$ & $1.78 \%$ \\
\hline $\mathrm{Cl}$ & 17.2002 & 0.0000 & 0.0000 & 0.0000 & 0.0000 \\
\hline $\mathrm{K}$ & $1.54 \%$ & $1.33 \%$ & $1.33 \%$ & $0.93 \%$ & $1.00 \%$ \\
\hline $\mathrm{CaO}$ & $73.66 \%$ & $55.47 \%$ & $57.61 \%$ & $61.43 \%$ & $61.68 \%$ \\
\hline $\mathrm{MnO}$ & $0.16 \%$ & $0.14 \%$ & $0.14 \%$ & $0.14 \%$ & $0.15 \%$ \\
\hline $\mathrm{Fe} 2 \mathrm{O}_{3}$ & $3.92 \%$ & $4.06 \%$ & $3.88 \%$ & $3.97 \%$ & $3.96 \%$ \\
\hline $\mathrm{ZnO}$ & $0.16 \%$ & $0.17 \%$ & $0.18 \%$ & $0.21 \%$ & $0.17 \%$ \\
\hline $\mathrm{As}$ & - & $0.66 \%$ & $0.74 \%$ & $0.88 \%$ & $0.63 \%$ \\
\hline
\end{tabular}

Table 10. Chemical composition of basalt when exposed to 8 days with arsenic in water.

\begin{tabular}{|c|c|c|c|c|c|}
\hline \multirow{2}{*}{$\begin{array}{c}\text { Chemical } \\
\text { composition }\end{array}$} & Reference & Day 2 & Day 4 & Day 6 & Day 8 \\
\cline { 2 - 6 } & \multicolumn{5}{|c|}{ Concentration (\%) } \\
\hline $\mathrm{Na}_{2} \mathrm{O}$ & $2.94 \%$ & $2.87 \%$ & $2.74 \%$ & $2.82 \%$ & $2.99 \%$ \\
\hline $\mathrm{MgO}$ & $2.68 \%$ & $2.36 \%$ & $2.64 \%$ & $2.43 \%$ & $2.75 \%$ \\
\hline
\end{tabular}


Tecnología y

Ciencias $\stackrel{\unlhd}{\unlhd}$ gua
2021, Instituto Mexicano de Tecnología del Agua Open Access bajo la licencia CCBY-NC-SA 4.0

(https://creativecommons.org/licenses/by-nc-sa/4.0/)

\begin{tabular}{|c|c|c|c|c|c|}
\hline $\mathrm{Al}_{2} \mathrm{O}_{3}$ & $19.77 \%$ & $19.91 \%$ & $20.06 \%$ & $20.28 \%$ & $19.90 \%$ \\
\hline $\mathrm{SiO}_{2}$ & $53.18 \%$ & $54.13 \%$ & $54.51 \%$ & $53.62 \%$ & $53.79 \%$ \\
\hline $\mathrm{P}_{2} \mathrm{O}_{5}$ & $0.28 \%$ & $\begin{array}{c}66.8332 \\
\mathrm{mg} \mathrm{I-1}\end{array}$ & $0.02 \%$ & $0.05 \%$ & $0.06 \%$ \\
\hline $\mathrm{SO}_{4}$ & $\begin{array}{c}0.001590 \\
4\end{array}$ & $\begin{array}{c}0.000466 \\
69\end{array}$ & $\begin{array}{l}0.0000 \\
\mathrm{mg} \mathrm{l}-1\end{array}$ & $\begin{array}{l}0.0000 \\
\mathrm{mg} \mathrm{l}-1\end{array}$ & $\begin{array}{l}0.0000 \\
\mathrm{mg} \mathrm{I-1}\end{array}$ \\
\hline $\mathrm{Cl}$ & $\begin{array}{c}90.9707 \\
\mathrm{mg} \mathrm{l}-1\end{array}$ & $\begin{array}{l}0.0000 \\
\mathrm{mg} \mathrm{l}-1\end{array}$ & $\begin{array}{l}0.0000 \\
\mathrm{mg} \mathrm{l}-1\end{array}$ & $\begin{array}{l}0.0000 \\
\mathrm{mg} \mathrm{l}-1\end{array}$ & $\begin{array}{l}0.0000 \\
\mathrm{mg} \mathrm{l-1}\end{array}$ \\
\hline $\mathrm{K}$ & $1.08 \%$ & $1.14 \%$ & $1.06 \%$ & 0.011581 & $1.05 \%$ \\
\hline $\mathrm{CaO}$ & $7.16 \%$ & $6.27 \%$ & $6.33 \%$ & $6.66 \%$ & $6.43 \%$ \\
\hline $\mathrm{TiO}_{2}$ & $1.81 \%$ & $1.96 \%$ & $1.89 \%$ & $1.94 \%$ & $1.88 \%$ \\
\hline $\mathrm{MnO}$ & $0.18 \%$ & $0.18 \%$ & $0.21 \%$ & $0.24 \%$ & $0.24 \%$ \\
\hline As & - & - & - & $10.69 \%$ & $10.78 \%$ \\
\hline $\mathrm{Fe}_{2} \mathrm{O}_{3}$ & $10.64 \%$ & $11.02 \%$ & $10.44 \%$ & $0.03 \%$ & $0.04 \%$ \\
\hline
\end{tabular}

The measurements of the chemical compositions obtained before and after the contamination of As for basalt and concrete with the EDXRF technique reveal that this heavy metal is retained in the solid part, due to the ionic exchange that exists through the elements that are related to As. This result could not be obtained with the TXRF technique. 


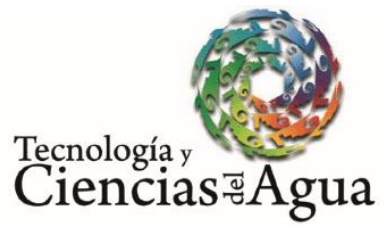

\section{Conclusions}

Based on the results obtained in this research, the authors reached the following conclusions.

Heavy metal pollution of urban and industrial stormwater is an issue that has provoked several problems. The research presented in this paper documented the development of permeable concrete using basalt as a stone aggregate for the retention of heavy metals from aqueous systems. The results demonstrated that the retention of cadmium, zinc, and arsenic is comparable or better than conventional systems. At low concentrations, adsorption was the main mechanism of removal. However, precipitation predominates at high concentrations. In addition, the migration of metals to the carbonate aggregate further increases the elimination capacity. The exposure of the permeable concrete to zinc, cadmium, and arsenic causes a decrease in the concrete paste that surrounds the basalt in the permeable concrete, this directly influences the diminution of the resistance of concrete when exposed to these contaminants. Exposure of permeable concrete with natural basaltic aggregate to solutions with concentrations of $1 \%, 3 \%, 5 \%$, and $9 \% \mathrm{Zn}, \mathrm{Cd}$, and As, causes a decrease in a concrete paste that envelops basalt in permeable concrete. This directly influences the decrease in concrete strength when exposed to these pollutants. Aluminum oxide (Al2O3), ferric oxide (Fe2O3), magnesium oxide ( $\mathrm{MnO}$ ), and silicon oxide ( $\mathrm{SiO} 2)$ containing basalt and 
Ciencias $₫$ Agua
2021, Instituto Mexicano de Tecnología del Agua

Open Access bajo la licencia CC BY-NC-SA 4.0

(https://creativecommons.org/licenses/by-nc-sa/4.0/)

cement contribute to the retention of As, Cd, and Zn, with As being the more related to these elements, so it has a higher retention efficiency.

Total Reflection X-Ray Fluorescence (TXRF) and Energy-dispersive X-ray Fluoresce (EDXRF) exhibits several advantages over the usually employed techniques for this type of analysis, focusing on operational cost and purchase, ease of sample and device handling, speed of analysis, and recovery of analyzed samples because the use of these techniques allows keeping the analyzed samples intact for future analysis.

The implementation of permeable concrete as a filter to purify water containing heavy metals may be of lower cost with respect to zeolite since cementitious materials and aggregate (basalt) make an efficient and lowcost product.

In summary, this paper presents broader results and more specific analyzes on the retention and treatment of heavy metals by permeable pavements, as well as the application and processes to determine the useful life of the system and its impacts in a natural environment by exposing residual chemical agents present after the process. Also, in order to explain the mechanism responsible for removal of heavy metals by basalt with specific concentrations in a complement information $\mathrm{f}$ the data obtained by Zhao and Zhao (2014), and Sounthararajah et al. (2017).

\section{Acknowledgments}

In addition, the work is also supported by the Universidad Autónoma de Queretaro (UAQ) and Universidad Autónoma de Sinaloa (UAS). 
Teçnología y

Ciencias $₫$ Agua
2021, Instituto Mexicano de Tecnología del Agua

Open Access bajo la licencia CC BY-NC-SA 4.0

(https://creativecommons.org/licenses/by-nc-sa/4.0/)

\section{References}

ACI, American Concrete Institute. (2010). Report on pervious concrete. Farmington Hills, USA: American Concrete Institute.

ACI-522R.6. (2006). Pervious concrete. Washington, DC, USA: American Concrete Institute.

Ammar, N. S., Ismail, A. I., \& El-Shafey, O. I. (2016). Engineering behavior influence of basaltic rocks on the adsorption of heavy metal ions. Desalination and Water Treatment, 57(11), 5089-5099. Recovered from https://doi.org/10.1080/19443994.2014.1003101

ASTM, American Society for Testing and Materials. (2015). Standard test method for relative density (specific gravity) and absorption of coarse aggregate (ASTM C127-15). West Conshohocken, USA: American Society for Testing and Materials.

Aydın, H., Bulut, Y., \& Yerlikaya, Ç. (2008). Removal of copper (II) from aqueous solution by adsorption onto low-cost adsorbents. Journal of Environmental Management, 87(1), 37-45. Recovered from https://doi.org/10.1016/j.jenvman.2007.01.005

Birch, G., \& Scollen, A. (2003). Heavy metals in road dust, gully pots and parkland soils in a highly urbanized subcatchment of Port Jackson, Australia, Australian Journal of Soil Research, 41, 1329-1342.

Borazjani, O., Ghiasi-Freez, J., \& Hatampour, A. (2016). Two intelligent pattern recognition models for automatic identification of textural and pore space characteristics of the carbonate reservoir rocks using thin section images. Journal of Natural Gas Science and Engineering, 35,944-955. 
Ciencias $₫$ Agua
2021, Instituto Mexicano de Tecnología del Agua

Open Access bajo la licencia CCBY-NC-SA 4.0

(https://creativecommons.org/licenses/by-nc-sa/4.0/)

Bruker. (2011). S2 PICOFOXTM, TXRFSpectrometer for element analysis, User Manual. Berlin, Germany: Bruker Nano GmbH.

Bruker. (2007). S2 PICOFOX Total Reflection X-ray Fluorescence Spectroscopy-Working Principles. Lab Report. Bruker AXS Microanalysis GmbH, Berlin, Germany (ReportNo. XRF 426). Billerica, USA: Bruker.

Delatte, N., Mrkajic, A., \& Miller, D. I. (2009). Field and laboratory evaluation of pervious concrete pavements. Transportation Research Record, 2113(1), 132-139. Recovered from https://doi.org/10.3141/2113-16

De-La-Calle, I., Cabaleiro, N., Romero, V., Lavilla, I., \& Bendicho, C. (2013). Sample pretreatment strategies for total reflection X-ray fluorescence analysis: A tutorial review. Spectrochimica Acta Part B: Atomic Spectroscopy, 90, 23-54. Recovered from https://doi.org/10.1016/j.sab.2013.10.001

Eloussaief, M., \& Benzina, M. (2010). Efficiency of natural and acidactivated clays in the removal of $\mathrm{Pb}$ (II) from aqueous solutions. Journal of Hazardous Materials, 178(1-3), 753-757. Recovered from https://doi.org/10.1016/j.jhazmat.2010.02.004

Haselbach, L., Poor, C., \& Tilson, J. (2014). Dissolved zinc and copper retention from stormwater runoff in ordinary portland cement pervious concrete. Construction and Building Materials, 53, 652657.

Recovered from https://doi.org/10.1016/j.conbuildmat.2013.12.013

Haselbach, L., Boyer, M., Kevern, J. T., \& Schaefer, V. R. (2011). Cyclic heat island impacts on traditional versus pervious concrete 
pavement systems. Transportation Research Record, 2240, 107115.

Javadi, S., Abdollahian, S., Zhao, Q., Ghavami, M., \& Rockaway, T. (2016). Effectiveness of heavy metal removal in urban permeable pavement systems. In: Geo-Chicago 2016 (pp. 22-31). Recovered from https://ascelibrary.org/doi/abs/10.1061/9780784480168.003

Komastka, S. H., Kerkhoff, B., \& Panarese, W. C. (2003). Design and control of concrete mixtures. Skokie, USA: Portland Cement Association.

Li, J., Zhang, Y., Liu, G., \& Peng, X. (2017). Preparation and performance evaluation of an innovative pervious concrete pavement. Construction and Building Materials, 138, 479-485.

Mangani, G., Berloni, A., Bellucci, F., Tatàno, F., \& Maione, M. (2005). Evaluation of the pollutant content in road runoff first flush waters. Water, Air, and Soil Pollution, 160(1-4), 213-228. Recovered from https://doi.org/10.1007/s11270-005-2887-9

Paulsen, G. Zacny, K., Dreyer, C. B., Szucsc, A., Szczesiak, M., Santoro, C., Craft, J., Hedlund, M., \& Skok, J. (2013). Robotic instrument for grinding rocks into thin sections (GRITS). Advances in Space Research, 51(11), 2181-2193.

Ponce-Lira, B., Otazo-Sánchez, E. M., Reguera, E., Acevedo-Sandoval, O. A., Prieto-García, F., \& González-Ramírez, C. A. (2017). Lead removal from aqueous solution by basaltic scoria: Adsorption equilibrium and kinetics. International Journal of Environmental Science and Technology, 14, 1181-1196. Recovered from https://doi.org/10.1007/s13762-016-1234-6. 
Tecnología y

Ciencias $₫$ Agua
2021, Instituto Mexicano de Tecnología del Agua

Open Access bajo la licencia CC BY-NC-SA 4.0

(https://creativecommons.org/licenses/by-nc-sa/4.0/)

Potgieter, J. H., Potgieter-Vermaak, S. S., \& Kalibantonga, P. D. (2006). Heavy metals removal from solution by palygorskite clay. Minerals Engineering, 19(5), 463-470. Recovered from https://doi.org/10.1016/j.mineng.2005.07.004

Sandahl, J. F., Baldwin, D. H., Jenkins, J. J., \& Scholz, N. L. (2007). A sensory system at the interface between urban storm-water runoff and salmon survival. Environmental Science \& Technology, 41(8), 2998-3004. Recovered from https://doi.org/10.1021/es062287r

Sounthararajah, D. P., Loganathan, P., Kandasamy, J., \& Vigneswaran, S. (2017). Removing heavy metals using permeable pavement system with a titanate nano-fibrous adsorbent column as a post treatment. Chemosphere, 168, 467-473. Recovered from https://doi.org/10.1016/j.chemosphere.2016.11.045

Starke, P., Wallmeyer, C., Rölver, S., Göbel, P., \& Coldewey, W. G., (2011). Development of a new laboratory evaporation measurement device as decision support for evaporation optimized building, Building and Environment, 46, 2552-2561.

Turer, D. (2005). Effect of non-vehicular sources on heavy metal concentrations of roadside soils. Water, Air, and Soil Pollution, 166(1-4), 251-264. Recovered from https://doi.org/10.1007/s11270-005-7378-5

Uma-Maguesvari, M., \& Narasimha V. L. (2013). Studies on characterization of pervious concrete for pavement applications. Social and Behavioral Sciences, 104, 198-207. 
Wang, S., \& Pang, Y. (2010). Natural zeolites as effective adsorbents in water and wastewater treatment. Chemical Engineering Journal, $156,11-24$.

Weiss, P. T., Kayhanian, M., Gulliver, J. S., \& Khazanovich, L. (2017). Permeable pavement in northern North American urban areas: research review and knowledge gaps, International Journal of Pavement Engineering, 234, 345-354.

Zhao, Y., \& Zhao, C. (2014). Lead and zinc removal with storage period in porous asphalt pavement. Water $S A, 40(1), 65-72$. Recovered from http://dx.doi.org/10.4314/wsa.v40i1.8 